\title{
Toothache tales: Part 2
}

\author{
M. E. Richardson ${ }^{1}$
}

The second part of the selection of literary excerpts on toothache deals with extraction as the ultimate curse. In common with killing a cat, there are many ways to do it.

\section{EXODONTIA; AMATEUR AND PROFESSIONAL}

In times past, the most common cure for toothache was extraction of the offending member, not always carried out by the qualified dentist under aseptic conditions. The amateur dentist comes in various guises.

Sam Hanna Bell ${ }^{1}$ recorded the reminiscences of an old woman in County Armagh.

\section{Music hath charms}

'This shoemaker had another job as well as mending boots; he extracted teeth. When you had toothache, you went to him and said you wanted your tooth taken out. He had little forceps for taking sparbles out of boots, and he put these forceps on the fire to sterilise them. When they were properly sterilised and cooled again, he sat his patient in a chair. Now, if there was any danger of the patient wanting to run out through the door, there were enough people round the walls to hold him down, and I believe that if he shouted a bit they started to sing, and they sang down his shouts. The cobbler never had any trouble. He wouldn't have pulled a tooth for anyone

\footnotetext{
${ }^{1}$ Margaret E Richardson,

Correspondence to: Associate Specialist Orthodontist (retired), 33 Cherryvalley Park, Belfast BT5 6PN N. Ireland Email:marich@cvparkbt56pn.freeserve.co.uk
}

\section{Refereed Paper}

Received 11.02.02; Accepted 18.03.02

๑ British Dental Journal 2002; 192: 709-713 under sixteen, and between sixteen and eighteen you brought your father with you. There was never any illness afterwards. As my father often said, there was a great dentist lost in that man.'

The Reverend James Woodforde ${ }^{2}$ turned to the local blacksmith for relief from his toothache. 'The Tooth-Ache so very bad all night and the same this morn' that I sent for John Reeves the farrier who lives at the Hart and often draws teeth for people, to draw one for me. He returned with my man about 11 o'clock this morning and he pulled it out for me the first pull, but it was a monstrous crash and more so, it being one of the eye teeth, it had but one fang but that was very long. I gave Johnny Reeves for drawing it 0.2.6. A great pain in the jaw bone continued all day and night but nothing so bad as the tooth ache.....

My tooth pained me all night, got up a little after 5 this morning, and sent for one Reeves a man who draws teeth in this parish, and about 7 he came and drew my tooth, but shockingly bad indeed, he broke away a great piece of my gum and broke one of the fangs of the tooth, it gave me exquisite pain all the day after, and my Face was swelled prodigiously in the evening and much pain. Very bad and in much pain the whole day long. Gave the old man that drew it however 0.2.6. He is too old, I think, to draw teeth, can't see very well'.

The veterinary surgeon made a good substitute for dentist or doctor in Carson McCullers'3 novel Clock Without Hands.
'When Doc Tatum died I had a terrible toothache - I think it was psychosomatic, so I went to Doc's brother who was the best mule doctor in the county.

"Mule doctor!" His faith in the Judge's reasoning echoed with a sick dismay. The old Judge did not seem to notice.

Naturally, it was the week of Doc's funeral, and what with the wake and cortege and all, my tooth hurt like an electric bell - so Poke, Doc's brother, just drew the tooth for me - with novocain and antibiotics which he uses for the mules anyhow, as their teeth are strong and they are very stubborn about anybody fooling with their mouths and very sensitive.'

An enterprising nursing colleague of Katherine Everett ${ }^{4}$ stepped into the breech in the absence of the dentist. 'The dental day was hard work, with a queue of people waiting. Extractions were done by a rotund little dentist, and cavities were prepared by the nurses. We became quite expert at cutting away decay, sometimes by hand, sometimes using the treadle, and observing our work in the magnifying reflector to see all was clean before the dentist did the actual filling. The work went on nearly all day, after which we would be left to tidy up.

One evening after the dentist, carrying his bag, had gone, the door burst open and a stout cab-driver in a shiny hat rushed in holding his jaw. We told him the dentist had gone and he must come the following week, upon which he responded with a cataract of despairing speech. His evil tooth must come 
out, for he could neither sleep nor eat, and he called on the saints to help him.

"I will take out his tooth."

This statement came from a self-effacing mouse of an amateur nurse and, coming from her, it seemed quite incredible.

"Have you ever taken out a tooth?" we asked.

"No, but people who do must have begun once, and I have seen so many taken out here that I am sure I can do it."

"We haven't the cocaine and the syringe."

"We must do without."

Then she became most professional, gagging his mouth and marking the tooth, after which she selected her forceps, tilted back the chair and stood on a footstool.

"Now, please all hold him and keep his head steady."

Hold him we had to, for at the first twist he gave a bellow and tried to bound from the chair. Unperturbed, the valiant little creature twisted and turned, and then drew out the bleeding fanged tooth, while great tears rolled down the victim's unshaven, crimson cheeks. He soon recovered, with the buoyancy natural to Italians, and for a moment we thought he was about to engulf the mouse-like nurse in an embrace, but he was only expressing gratitude and admiration, and he went off with his head wound about in a purple muffler.'

\section{ALL IN THE FAMILY}

The skills of the father were visited on the son in Anthony Burgess's ${ }^{5}$ Earthly Powers 'The surgery bell buzzed loudly. There was a middle-aged man at the door, a kind of

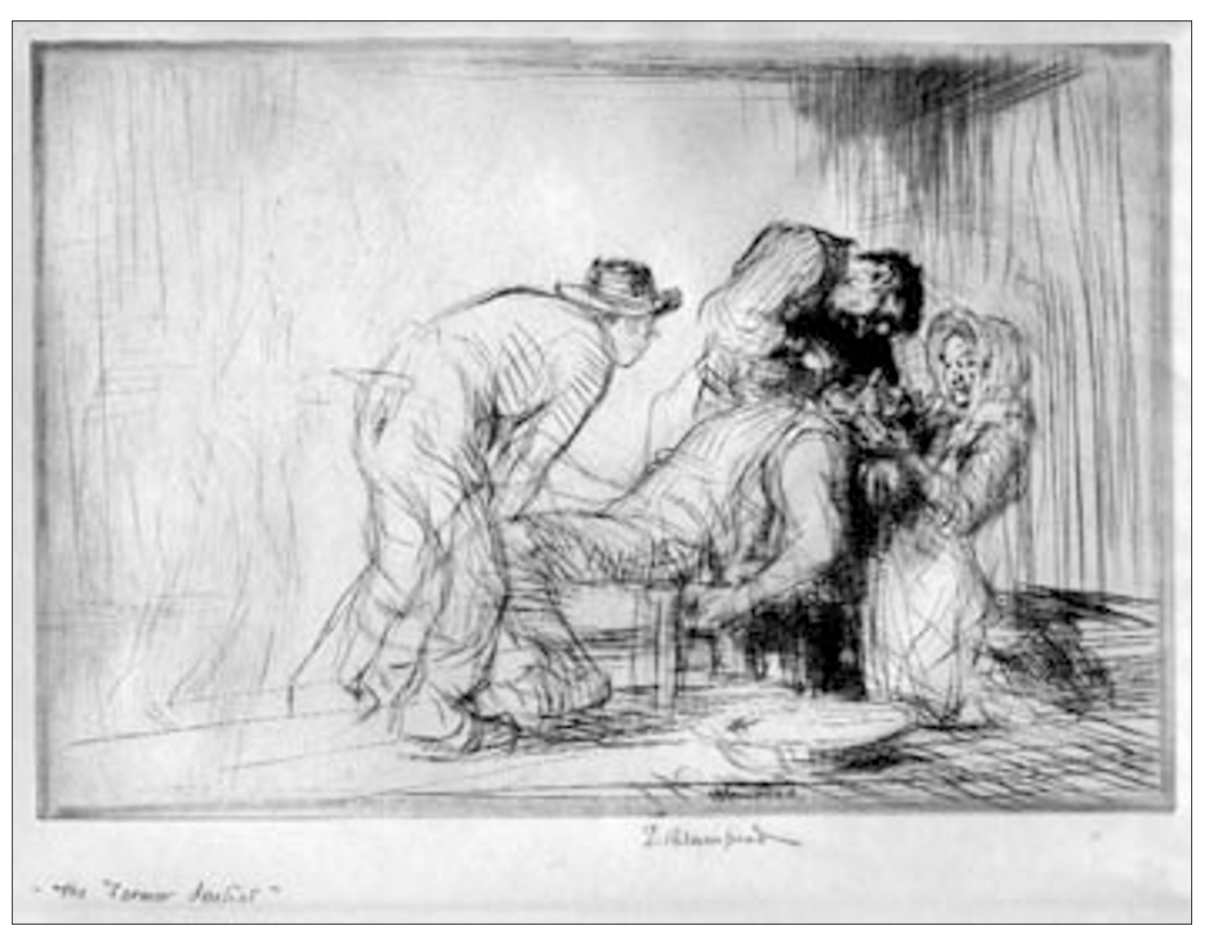

The Farmer Dentist (1880) by Edward Blampied. Etching on paper (4th plate) LDBDA P52 ostler to judge from his smell. He had raging toothache; he needed my father.

"He's gone to St Leonard's. To church."

"What for? Want me Christmas dinner like everybody else. It ain't fair."

I took him into the surgery. The soldier on the wall looked in fearful exophthalmia at burning Pompeii. "You should look after your teeth, "I said. "You should get your teeth ready for Christmas." I looked for oil of cloves but could see none. There were forceps there, though, neatly laid in lines, shining in the Christmas morning light. "Sit in that chair," I ordered. "Let's have a look at it"

"Here it's the dentist I want. You're not a dentist,"

"Like Christian baptism," I said. "Anybody can do it in case of emergency. Open." He opened and let out a hogo of medicinal rum and beer. The bad tooth was a premolar. It wobbled when I fingered it.

"Hurts, that does, ow."

"You don't want an anaesthetic, do you? It may upset your stomach"

"I want something that will kill the pain,"

"Through fire," I said "to peace and cool and light." I took the largest forceps in my right hand, pushed back the chair, inserted the pincers and caught the tooth, squeezing hard to hold it. He kept his mouth well open in protest and pain, ow for both. I worked the tooth to and fro, felt it loosen and then break from its moorings, and then pulled it out. "Spit," I said. He spat, howling from a pursed mouth. "Rinse," I said. I gave him cold water. "Better," I said. "Better now, eh?" I showed him the decayed horror at the end of the tongs. When he could speak he said:

"There ought to be a law."

"Don't grumble. I'm not charging you anything. Call this a Christmas gift."

He went off, bleeding, grousing about bloody butchers. I threw the tooth into the kitchen stove and rinsed the forceps under the kitchen tap. There was blood on my fingers but I did not at first wash it off. A corporal work of mercy and the badge thereof. If I were to be good in this, my post-Christian life, it must be totally without hope of reward.'

\section{I. Y. EXTRACTION}

Self help was one of the few options available in that remote part of the American deep south where Harry Crews ${ }^{6}$ spent his childhood.

'Mr Willis......did have very bad teeth, perhaps from sucking on tobacco day and night. His reticence and courtly manner never left him except when the pain from his teeth was on him bad....

I slept in a room on the other side of the wall from him. One night....Mr Willis' mouth came alive with what had to be an unthinkable pain.

When I heard him kick the slop jar, I knew it was his teeth. I just didn't know right away how bad it was. When the ladder-back chair splintered, I knew it was a bad hurt even for him... Ordinarily, mama would have fixed a hot poultice for his jaw or at least tried to do something. But she had learned he was a proud man and preferred to suffer by himself, especially if it was his teeth bothering him.... I heard him kick open the door to his room and thump down the wooden steps in his heavy brogan work shoes... He headed straight for the well.....took the bucket from the nail... and sent it shooting down as hard as he could to break the inch of ice that was over the water... He held the bucket and took a mouthful of the freezing water. He held it a long time, spat it out, and filled his mouth again.... With his cheeks swelling with water he took something out of the pocket of his overalls....He had a piece of croker sack about the size of a half dollar in his left hand and a pair of wire pliers in his right. He spat the water out and reached way back in his rotten mouth and put the piece of sack over a tooth. He braced his feet against the well and stuck the pliers in over the sackcloth. He took the pliers in both hands, and immediately a forked vein leaped in his forehead. The vein in his neck popped as big as a pencil. He pulled and twisted and pulled and never made a sound.

It took him a long time, and finally, as he fought with the pliers and with himself, his braced feet slipped so that he was flat 


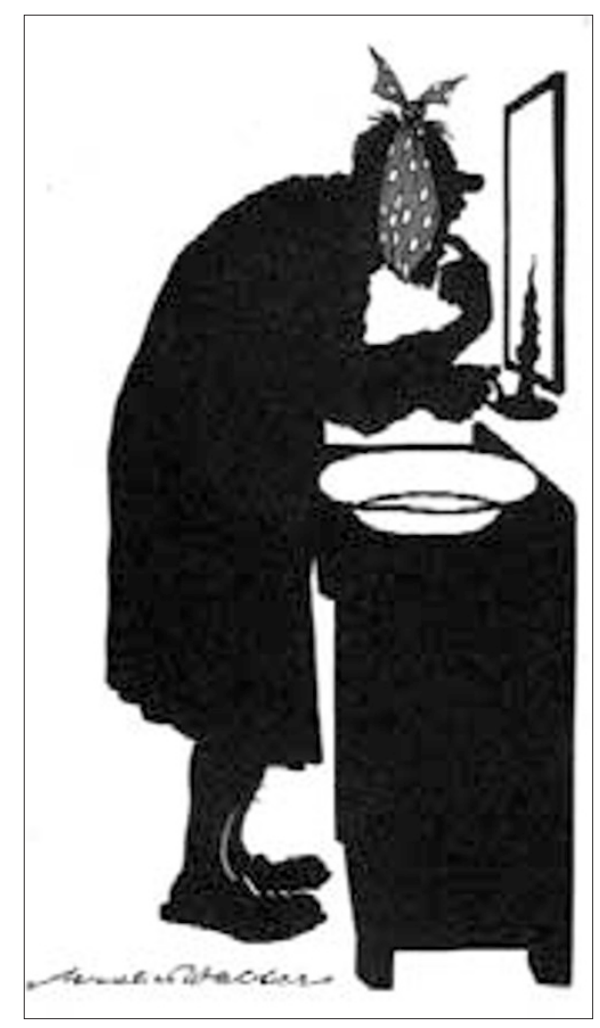

Untitled image of extraction by Matthias Walter (n.d.) Postcard LDBDA E90

on his back when the blood broke from his mouth, followed by the pliers holding a tooth with roots half an inch long. He got slowly to his feet, sweat running on his face, and held the bloody tooth up between us.

He looked at the tooth and said in his old, calm, recognizable voice: "Hurt now, you sumbitch!"'

Mark Twain's ${ }^{7}$ version of a time-honoured method was employed by Aunt Polly in Tom Sawyer.

“"Aunt Polly, it seemed mortified, and it hurt so; I never minded my tooth at all"

"Your tooth, indeed! What's the matter with your tooth?"

"One of them's loose, and it aches perfectly awful."

"There, there now, don't begin that groaning again. Open your mouth. Well, your tooth is loose, but you're not going to die about that. Mary, get me a silk thread and a chunk of fire out of the kitchen."

Tom said:

"Oh, please Auntie, don't pull it out, it don't hurt any more. I wish I may never stir if it does. Please don't Auntie; I don't want to stay at home from school."

"Oh, you don't, don't you? So all this row was because you thought you'd get to stay home from school and go a-fishing? Tom, Tom, I love you so, and you seem to try every way you can to break my old heart with your outrageousness."

By this time the dental instruments were ready. The old lady made one end of the silk thread fast to Tom's tooth with a loop and tied the other to the bed-post. Then she seized the chunk of fire and suddenly thrust it almost into the boy's face. The tooth hung dangling by the bed-post, now.

But all trials bring their compensations. As Tom wended to school after breakfast, he was the envy of every boy he met because the gap in his upper front row of teeth enabled him to expectorate in a new and admirable way. He gathered quite a following of lads interested in the exhibition; and one that had cut his finger and had been a centre of fascination and homage up to this time, now found himself suddenly without an adherent, and shorn of his glory. His heart was heavy, and he said with a distain which he did not feel, that it wasn't anything to spit like Tom Sawyer; but another boy said "Sour grapes!" and he wandered away a dismantled hero.'

Among all these expert amateur exodontists, it might be expected that the dental student would rate highly. The method proposed by Crazy Eyes in E. Annie Proulx's ${ }^{8}$ Postcards is unlikely to endear him to the patient. 'The throb of Loyal's tooth shook the truck. Another abscess for sure. He wrenched two beers from the cooler in the back, passed one to Crazy Eyes. Would have to dig out the whiskey to make it through the night.......It would be all right if it wasn't for the tooth. Crazy Eyes had ideas. But was he any good with a pair of pliers?

"You ever pull a tooth?"

The student wrenched round in his seat and glared. "Horsley told you, didn't he. The son of a bitch."

"Told me what?"

"About dental school. That I was in dental school until I switched to palaeontology. It was the teeth that got me interested in this."

"He didn't tell me, but that's the best news I heard today. I got a son of a bitch thumpin' in my jaw."

"How tough are you?"

"Oh, I had 'em pulled before with pliers. That what you mean?"

"Nah. They showed us this movie in dental school. Some tribe that knocks out boys' teeth with a big stick as the highlight of a puberty rite. I always wanted to try it."'

\section{A TOOTH FOR A TOOTH}

Another story related by Sam Hanna Bell ${ }^{1}$ and ascribed to one Morgan Jellett in 1769. 'I had a relative called Rawdon Stothard who lived near Moira. Suffering from toothache, he went to a self-created doctor in Moira named Charters, famous for drawing teeth and bleeding. Unfortunately for Dr Charters, he drew a sound tooth, and not the unsound one. "An eye for an eye and a tooth for a tooth," exclaimed Stothard, and being a powerful man, seized the luckless Charters and holding him down, drew one of his teeth. "Now," said Stothard, "try for my unsound one and if you mistake again I'll assuredly draw two of your remaining best teeth, and so on, until I bring you into good practice." Charters' next attempt was successful, and he was given a guinea for his trouble.'

\section{A FINGER FOR A TOOTH}

Peter Mayle $^{9}$ recounted the story of Bernard, a French peasant with a nasty habit, anathema to dentists. :...Bernard explained why he hadn't been able to come earlier. He had been suffering from toothache, but couldn't find a local dentist who was prepared to treat him, because of his strange affliction: he bites dentists. He can't stop himself. It is an incurable reflex. The moment he feels an exploratory finger in his mouth - tak! - he bites, He had so far bitten the only dentist in Bonnieux, and four dentists in Cavaillon, and had been obliged to go to Avignon, where he was unknown in dental circles. Fortunately, he had found a dentist who had fought back with an anaesthetic, knocking Bernard out completely while the repair work was done. The dentist told him afterwards that he had a mouthful of eighteenth-century teeth.

Eighteenth-century or not, they looked very white and healthy against Bernard's black beard as he laughed and talked.'

\section{AN EYE FOR A TOOTH}

A much more serious matter was reported by Norman Douglas. ${ }^{10}$ 'For a few days we had to live under canvas at Peshawar, where we were in a critical position and expecting an attack, or a revolt in the city, or both, at any moment. The troops used to come back from the front demoralised by the incessant rear-guard actions and snipings; casualties were comparatively heavy, and incredible tales were told of the inefficiency of the Army Medical Corps, or whatever it was called.

One of them has stuck in my mind. A private complained of a pain in one eye; it was unendurable. The eye was examined, and nothing found to be wrong with it. The pain, however, grew so violent that he was half-maddened and implored them to take it out; he could bear it no longer. This was done; the pain went on. They had taken out the wrong eye! Now the man threatened to kill himself if the remaining eye was not also removed; total blindness, he vowed, would be a trifle in comparison to the torture he was undergoing. They consented; the pain went on. It was then discovered that he had something the matter with one of his teeth.' 


\section{THE QUICK SNATCH}

Arthur Miller's ${ }^{11}$ dentist was not one to waste much time.

'(She once sent me down alone-I was seven at the time - to the dentist, a Dr Herbert on the ground floor, at two o'clock in the morning when I got a sudden toothache. I rang his bell and he opened his door in his pyjamas and looking down saw me in mine and almost without a word shuffled in his slippers into his office, where he turned on the light, motioned me to sit in the chair, took out a pair of forceps, asked, "Which one?" and following my finger, pulled it out. So rapidly did it all happen, with none of the preparatory reassurances and timeconsuming, apprehension-feeding preliminaries, that I hardly had time to yell before I was out his door and ringing the elevator button to go back upstairs, where I found everybody fast asleep.)'

\section{SCHOOL DENTISTRY}

The Master, Bryan McMahon ${ }^{12}$ painted a gruesome picture of the school dental service in rural Ireland in the 1930's. 'In the earlier part of my teaching days in the bad black building the visit of the dentist had to be endured to be believed. In later years the children were sent to the dentist's surgery, and this was certainly a huge change for the better. I still cannot forget the pan of blood of the old days, placed on a chair at the side of the crowded classroom, where the lesson went ahead while the brave little patient fought his fear of the forceps that extracted his rotten tooth

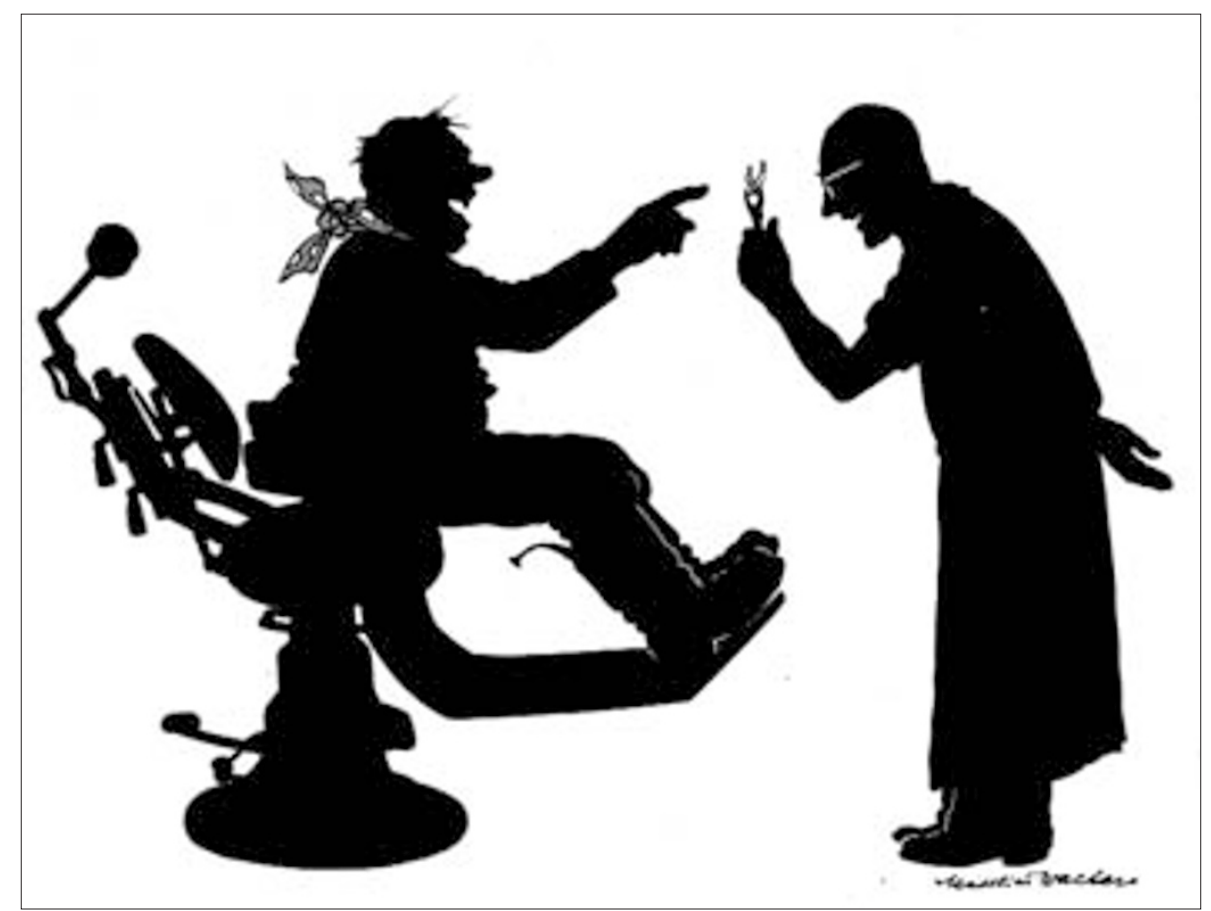

Untitled image of extraction by Matthias Walter (n.d.) Postcard LDBDA E90

in the sidelong and terrified view of the class.

Now and again one of the watching children slewed off the bench and was taken out in a dead faint. A scene straight out of Dickensian England; yet no-one seemed to think it odd.

I had witnessed similar scenes in the neighbouring marketplace of my youth: the "black doctor" holding aloft a bloody molar

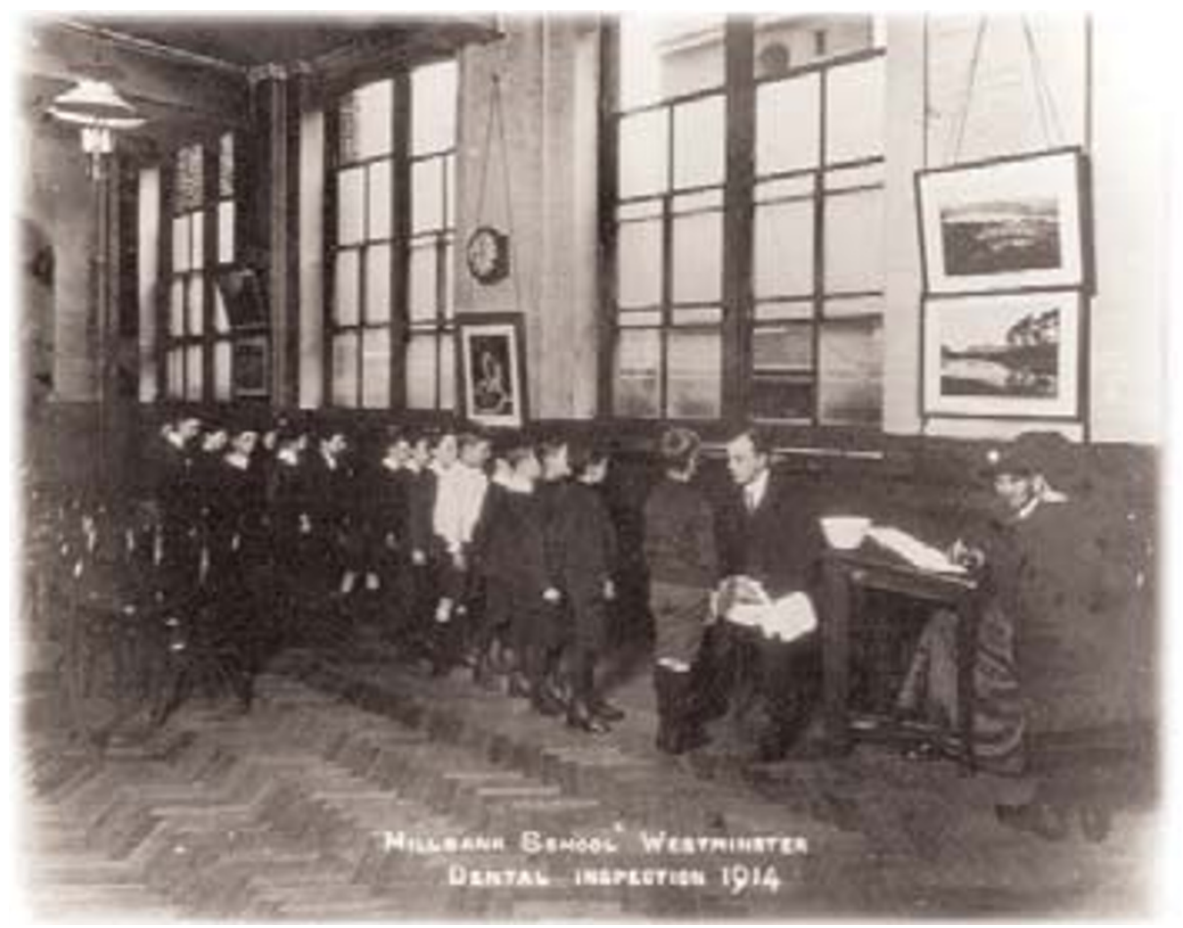

Millbank School, Westminster. Dental Inspection 1914. Black and white photographic print. Turner Collection LDBDA T20 that he had extracted with his powerful fingers from a farmer's jawbone, while a ring of country folk gaped their approval.'

\section{ONE OUT ALL OUT}

The travelling dentist was not unique to rural Ireland. The South American version appeared in Gabriel García Márquez's ${ }^{13}$ Love in the Time of Cholera. 'The loss of his teeth, on the other hand, did not result from a natural calamity but from the shoddy work of an itinerant dentist who decided to eradicate a simple infection by drastic means. His terror of the drill had prevented Florentino Ariza from visiting a dentist, despite his constant toothaches, until the pain became unbearable. His mother was alarmed by a night of inconsolable moaning from the room next to hers, because these moans seemed to be the same as the ones from another time, which had almost disappeared in the mists of her memory, but when she made him open his mouth to see where it was hurting him, she discovered that he had fallen victim to abscesses.

Uncle Leo X11 sent him to Dr. Francis Adonay, a black giant in gaiters and jodhpurs who travelled the riverboats with complete dental equipment that he carried in a steward's saddlebag, and who seemed to be more like a travelling salesman of terror in the villages along the river. With just one glance in his mouth, he decided that Florentino Ariza had to have even his healthy teeth and molars extracted in order to protect him once and for all from further misfortunes. In contrast to baldness, this radical treatment caused him no alarm at all, except for his natural fear of a bloodbath 
without anaesthesia. The idea of false teeth did not disturb him either, first because one of his fondest childhood memories was of a carnival magician who removed his upper and lower teeth and left them chattering by themselves on a table, and second because it would end the toothaches that had tormented him ever since he was a boy, with almost as much cruelty as the pains of love. Unlike baldness, it did not seem to him an underhand attack by old age, because he was convinced that despite the bitter breath of vulcanised rubber, his appearance would be cleaner with an orthopedic smile. So he submitted without resistance to the red-hot forceps of Dr Adonay, and he endured his convalescence with the stoicism of a pack mule.'

\section{AN IRONICAL EXTRACTION}

John Osborne, ${ }^{14}$ actor and playwright was '... rehearsing 'You Never Can Tell' in which I was to play the dentist.... and a sickening toothache overcame me.... I found the dentist unaided. He took out two of my teeth, leaning on my chest and tugging at them as they crunched like rocks in my head. "You've got teeth like a horse," he said chattily. Minutes later I was hovering over Shaw's dentist's chair in my white jacket, mouthing his facetious lines with a gumful of blood.'

William Saroyan ${ }^{15}$ suffered from poor dental health and had a love/hate relationship with dentists. 'Teeth bugged me from the earliest times of my involvement in the human experience. Their weaknesses, their sensitivity to hot and cold, to mysterious accidents of deterioration, their nerve leapings, their dull achings gave me a bad time beginning at the age of seven or eight.... I lost a fifth-year molar at the age of eleven. The experience was so traumatic it put me to hating dentists.

On Armistice Day, on the dreariest day of the year so far, three upper left teeth, with dental work in them from as long ago as forty years, have gone wrong. Are they decayed under the inlays, or is the hardware loose, or what?.......

The raw red nerve in the bad tooth has not given over to the dentist's theory of withdrawing and becoming serene: the idea isn't working. What am I supposed to do? Get up and give three cheers to dentistry?.......
I phoned the dentist and was there in fifteen minutes. He shot the long needle into the gum, the whole left side of the face went dead, but especially the huge lumpy nose. He then put the pliers upon the bad tooth, eased it to and fro, and after less than thirty seconds, it was out, and I looked at it.

I felt so good, I wandered around town for two hours.'

\section{DECEIVED}

Janet Frame ${ }^{16}$ was very unhappy with the way she was tricked into anaesthesia for childhood dental extractions. The experience blighted her dental future. 'And Wyndham was the time of the dentist and starting school and Grandma Frame's dying: all three memorably unhappy, although Grandma Frame's death was different in being world-sad with everyone sharing - the cows, the hens, the pet rabbit, even the stinky ferret as well as the family and relations - while going to the dentist and starting school were miseries that belonged only to me.

The visit to the dentist marked the end of my infancy and my introduction to a threatening world of contradictions where spoken and written words assumed a special power.'

One night, after Dad had "bag piped" us to sleep, I woke crying with a painful tooth. Dad came to where I lay in the cot, which was too small for me, as my feet touched the bars at the end. "I'll tan your backside," Dad said. His hand stung, hitting again and again on my bare bottom, and I cried again and at last fell asleep, and in the morning, faced the inevitable teasing of Myrtle and Bruddie - "You had a hiding last night!" I said calmly, "Well, I was cold anyway and it warmed my bottom."

I was taken to the dentist, where I kicked and struggled, thinking that something dire was about to happen to me, while the dentist, in the midst of my struggles, beckoned to the nurse, who came forward holding a pretty pink towel. "Smell the pretty pink towel" she said gently, and, unsuspecting, I leaned forward to smell, realising too late as I felt myself going to sleep that I'd been deceived. I have never forgotten that deception and my amazed disbelief that I could have been so betrayed, that the words "Smell the pretty pink towel," without any hint of anything fearful happening, had been used to lure me into a kind of trap, that they had not really meant "Smell the pretty pink towel," but "I'm going to put you to sleep while I take your tooth out." How could that have been? How could a few kind words mean so much harm?

Grandma's death and burial contained none of the fury and resulting distrust of the visit to the dentist.'

Other literary references to toothache and its cures, too long for inclusion in this article, are recommended for further reading. Maya Angelou's ${ }^{17}$ childhood encounter with racism in the first volume of her autobiography I Know Why Caged Birds Sing, the extraction of Mr Povey's tooth in Arnold Bennet's ${ }^{18}$ The Old Wives Tale, Miss Greene's treatment in Philip Larkin's ${ }^{19} \mathrm{Jill}$, the management of Edal the Otter's toothache in Gavin Maxwell's ${ }^{20}$ Ring of Bright Water, a short story entitled Surgery by Anton Chekov ${ }^{21}$ and Robert Burns'22 well known Address to the Toothache.

1. Bell SA. Within our province. Belfast: Blackstaff Press, 1972.

2. Woodforde J. The diary of a Country Parson. Oxford: OUP, 1929.

3. McCullers C. Clock Without Hands. Middlesex: Penguin, 1961.

4. Everett K. Bricks and Flowers. London: Constable and Co, 1949.

5. Burgess A. Earthly Powers. London: Hutchinson, 1980

6. Crews H. A Childhood. Athens, Georgia: University of Georgia Press, 1995.

7. Twain M. The Adventures of Tom Sawyer. London: Collins, 1953.

8. Proulx E. A. Postcards. London: Harper and Collins, 1994.

9. Mayle P. A Year in Provence. Middlesex: Penguin, 1989.

10. Douglas N. Looking Back. London: Chatto and Windus, 1934.

11. Miller A. Timebends. London: Methuen Ltd, 1987

12. McMahon B. The Master. Dublin: Poolbeg, 1992.

13. Márquez G G. Love in the Time of Cholera. London: Penguin, 1988.

14. Osborne J. A Better class of person. London: Faber and Faber, 1981.

15. Saroyan W. Days of Life and Death and Escape to the Moon. London: Michael Joseph, 1970.

16. Frame J. To the Is-land. London: The Womens Press, 1983.

17. Angelou Maya I Know Why Caged Birds Sing. London: Virago, 1969

18. Bennett A. The Old Wives Tale. London: J M Dent and Sons, 1968.

19. Larkin P. A Girl in Winter. London: Faber and Faber 1947.

20. Maxwell G. The Rocks Remain. London: Longmans Green and Co, 1963.

21. Chekov A. Selected Stories. New York: Signet Classics, 1884.

22. Burns R. Address to the toothache. The National Burns. London: Wmm Mackenzie, 1786. 